\title{
The discovery of a novel compound with potent antitumor activity: virtual screening, synthesis, biological evaluation and preliminary mechanism study
}

\author{
Yuanyuan Jin' ${ }^{1, *}$, Linhu Li ${ }^{1, *}$, Zhaoyong Yang ${ }^{1}$, Mingliang Liu ${ }^{1}$, Huiyuan Guo ${ }^{1}$, Weiyi \\ Shen ${ }^{2}$ \\ ${ }^{1}$ Institute of Medicinal Biotechnology, Chinese Academy of Medical Sciences and Peking Union Medical College, Beijing \\ 100050, China \\ ${ }^{2}$ Zhejiang Starry Pharmaceutical Co. Ltd., Xianju 317300, China \\ *These authors contributed equally to this work \\ Correspondence to: Mingliang Liu, email: Imllyx@126.com \\ Weiyi Shen, email: swy109@starrypharma.com \\ Keywords: anti-tumor, synthesis, virtual screening, farnesyltransferase inhibitor
}

Received: December 15, $2016 \quad$ Accepted: February 08, $2017 \quad$ Published: February 21, 2017

Copyright: Jin et al. This is an open-access article distributed under the terms of the Creative Commons Attribution License (CC-BY), which permits unrestricted use, distribution, and reproduction in any medium, provided the original author and source are credited.

\section{ABSTRACT}

Farnesyltransferase has been regarded as a promising drug target against cancer as it is critical for membrane association of several signal transduction proteins. In this study, a novel farnesyltransferase inhibitor (IMB-1406) was identified through virtual screening. It exhibits stronger potency $\left(\mathrm{IC}_{50} \mathrm{~S}: 6.92-8.99 \mu \mathrm{M}\right)$ than Sunitinib against all of the tested cancer cell lines. Preliminary studies on mechanism reveal that IMB-1406 induces apoptosis in HepG2 cells by arresting the cell cycle at the $S$ phase, altering anti- and pro-apoptotic proteins leading to mitochondrial dysfunction and activation of caspase-3. This anti-tumor effect is most probably related to the inhibition of farnesyltransferase as indicated by molecular docking. Overall, IMB1406 is a novel lead compound with potent antitumor activity and deserves further structural modifications.

\section{INTRODUCTION}

Cancers still remain the second leading cause of death worldwide after cardiovascular diseases [1]. Many classes of antitumor agents, especially tyrosine kinase (TK) inhibitors, have been introduced to the market during the last decade, and more candidates are now under development [2]. However, given the emergence of drug resistance and the low success rate in clinical development, the discovery of novel chemical compounds with a completely new mode of action is clearly needed.

The Ras genes encode more than 100 proteins, collectively known as the Ras superfamily, which are involved in the regulation of proliferation, differentiation, cell adhesion and apoptosis of cells. Some of these proteins are small $G$ proteins that transducer signals from cellsurface receptors, such as growth factor receptors, and then transmit the signals to several different pathways, ultimately affect mitogenic functions such as DNA synthesis, cytoskeletal organization and lipid metabolism. Disruption of these signal transduction pathways through mutation of the Ras genes involved in many tumor types [3].

Farnesylation is a type of lipid modification called protein prenylation that is critical for biological functionality, including membrane association of several signal transduction proteins. Oncogenically mutant forms of human Ras superfamily proteins are associated with $30 \%$ of all human cancers; the transforming ability of these mutants is dependent upon farnesylation. More recently, farnesyltransferase has become popular drug targets $[4,5]$. Inhibitors of farnesyltransferase cause tumor regression in animals and are currently being evaluated in clinical trials for the treatment of human cancers [6-8]. Farnesyltransferase inhibitors (FTIs) that have been or are being investigated in clinical trials include lonafarnib (SCH66336; Sarasar ${ }^{\mathrm{TM}}$; Schering-Plough), tipifarnib (R115777; Zarnestra ${ }^{\mathrm{TM}}$; Ortho BiotechProducts), L778123 (Merck), BMS-214662 (Bristol-MyersSquibb), and salirasib (S-trans,trans-farnesylthiosalycilic acid, FTS, Concordia Pharmaceuticals) [9]. However, none 
of these have yet been approved by FDA for clinical treatments. Therefore, it is imperative to develop more new FTIs.

Computer-aided drug design is one of most effective methods in developing new drugs. Many reports have indicated that computational method is a time-saving and effort-saving approach to discover new candidates including molecular docking [10], virtual screening [11], and 3DQSAR [12, 13]. Virtual screening (VS) has emerged as a powerful approach to complement the array of existing high-throughput screening technologies $[14,15]$. Using computer-aided VS, potential leads can be rapidly identified in silico in order to narrow the range of molecules to be tested in vitro and in vivo. In this study, virtual screening was used as a 3D query in an in-house chemical database over 900 compounds screening to retrieve potential FTIs.

\section{RESULTS AND DISCUSSION}

\section{Virtual screening}

Virtual screening of chemical databases can serve the purpose of finding novel potential leads suitable for further development. Molecular docking technology which has been increasingly used in the course of drug research and development is the representative of receptor-based virtual screening $[16,17]$. In this paper, molecular docking experiments were carried out using Discovery Studio 2.5 software (Accelrys Inc., San Diego, CA, USA) with fully automated docking tool using "CDOCKER" protocol [18-22] employing CHARMm force field to investigate the possible inhibitors for farnesyltransferase. The CDOCKER energy (-(protein-ligand interaction energies)) of best poses docked into the receptor of all the 900 compounds was calculated and compared with that of Compound 4 which is a new potent farnesyltransferase inhibitor based on the ethylenediamine scaffold. As a result, IMB-1406 was found to have the highest CDOCKER energy and similar structural framework to the crystallized inhibitor (Compound 4) [23] of farnesyltransferase, as shown in Figure 1.

According to the docking result, the most active compound IMB-1406 and the Compound 4 are found to bind in the active pocket of farnesyltransferase receptor in a similar conformation (Figure 2). As described above, both the para-benzonitrile moiety of the Compound 4 and the 6-bromo-2-methoxyquinoline one of IMB-1406 are oriented toward the product exit groove and are partially stabilized by a stacking interaction with $\mathrm{Y} 361 \beta$. In Figure $2 \mathrm{~B}$, there are three hydrogen bonding interactions between the N22 and $\mathrm{O} 33$ positions of IMB-1406 and R202 $\beta$. This is consistent with the -CDOCKER_INTERACTION_ENERGY between the two compounds and the farnesyltransferase. The highest -CDOCKER_INTERACTION_ENERGY was 52.24 for IMB-1406 and that of Compound 4 was 57.22, suggesting that IMB-1406 could have similar affinity with the Compound 4 and the farnesyltransferase might be one of the possible targets for IMB-1406.

\section{Chemical synthesis}

Detailed synthetic pathway to compound IMB-1406 is depicted in Scheme 1. Treatment of ethambutol $(\mathrm{EMB}, 1)$ with tert-butyldimethylsilyl chloride (TBDMSCl) gave the desired bis-TBDMS-protected compound 2. The coupling of the resulting diamine 2 with intermediate 3 (22) and then deprotection of the hydroxyl groups with tetrabutylammonium fluoride (TBAF) in tetrahydrofuran (THF) yielded the target compound IMB-1406 (Scheme 1).

\section{Antitumor activity}

For preliminary screening of antitumor activity, IMB1406 was first investigated for cytotoxic activity against A549 (lung adenocarcinoma), MCF-7 (breast cancer), DU145 (prostate carcinoma) and HepG2 (liver carcinoma). Then the compound was further evaluated for its in vitro anti-tumor activity against the aforementioned four human cancer cell lines by the MTT assay. The inhibition rate and $\mathrm{IC}_{50}$ values were compared with those of Sunitinib, a multitargeted receptor TK inhibitor [24] (Table 1). IMB-1406 exhibits remarkable anti-tumor activity (inhibition rate: $\left.99.93 \%-100.39 \%, \mathrm{IC}_{50} \mathrm{~s}: 6.92-8.99 \mu \mathrm{M}\right)$ which is better than Sunitinib (inhibition rate: $86.51 \%-100.02 \%, \mathrm{IC}_{50} \mathrm{~s}$ : $7.60-10.36 \mu \mathrm{M})$ against these cancer cell lines, and thus is selected as the lead compound for preliminary mechanism study on the growth inhibition of HepG2 cells.

\section{Effects of IMB-1406 on cell cycle of HepG2 cells}

To understand the mechanisms underlying the action of IMB-1406, the effects of IMB-1406 on HepG2 cell cycle were examined. HepG2 cells were treated with the indicated concentrations of IMB-1406 for $72 \mathrm{~h}$ and stained with propidium iodide (PI), followed by flow cytometry analysis. As shown in Figure 3, the percentages of HepG2 cells in the S phase are $28.17 \%(2 \mu \mathrm{M}), 36.96 \%(4 \mu \mathrm{M})$ and $37.25 \%(8 \mu \mathrm{M})$, respectively, which are significantly higher than that of the vehicle treated controls $(26.43 \%)$. Hence, IMB-1406 inhibits the growth of the cancer cells by inhibiting the cell cycle via S-phase arrest.

\section{Effects of IMB-1406 on induction of HepG2 cell apoptosis}

Apoptosis plays a central role in cancer treatment, since its induction in cancer cells is critical to a successful therapy $[25,26]$. It is thus believed that apoptosis assay may provide important information to the preliminary investigation of the mode of action. The impact of IMB1406 on the apoptosis of HepG2 cells was examined 


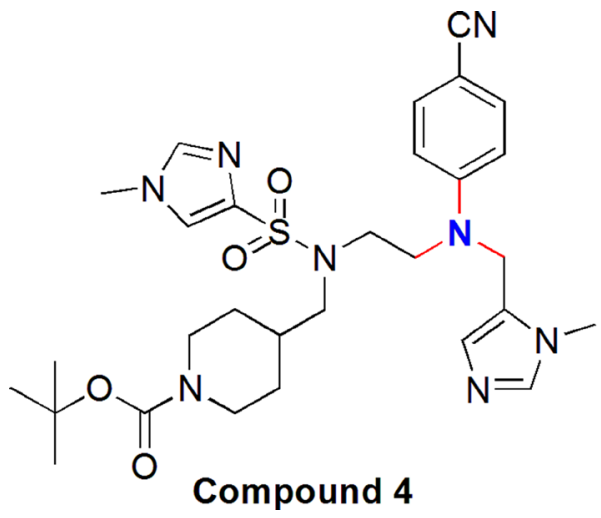<smiles>CC[C@H](CO)NCCN(C(c1ccccc1)c1cc2cc(Br)ccc2nc1OC)[C@H](CC)CO</smiles>

IMB-1406

Figure 1: Chemical structures of Compound 4 and the most active compound IMB-1406 used in the present study.
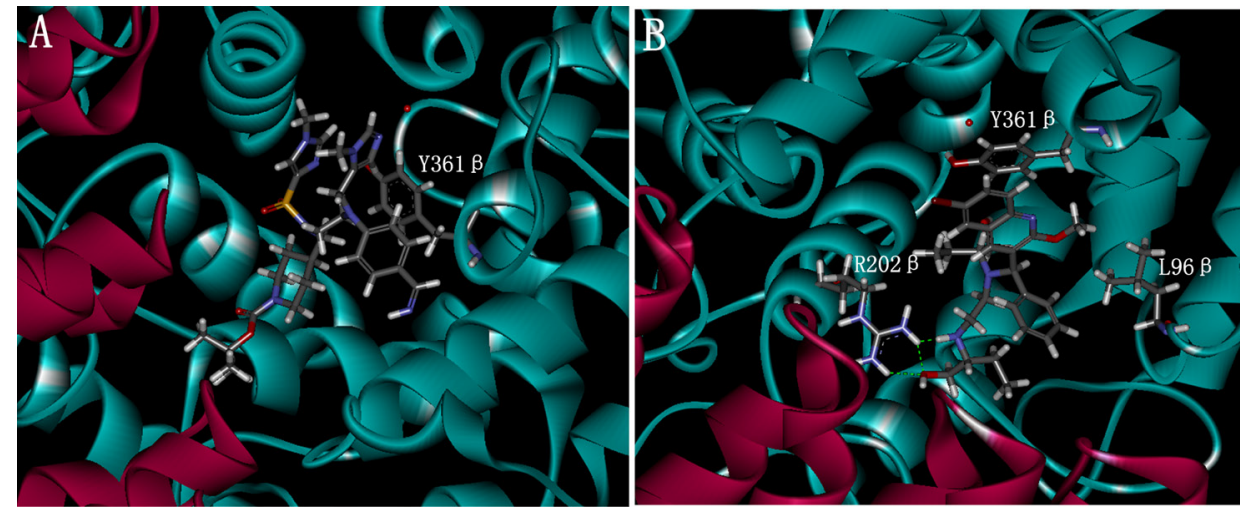

Figure 2: Docking of the Compound 4 (A) and the compound IMB-1406 (B) with farnesyltransferase.

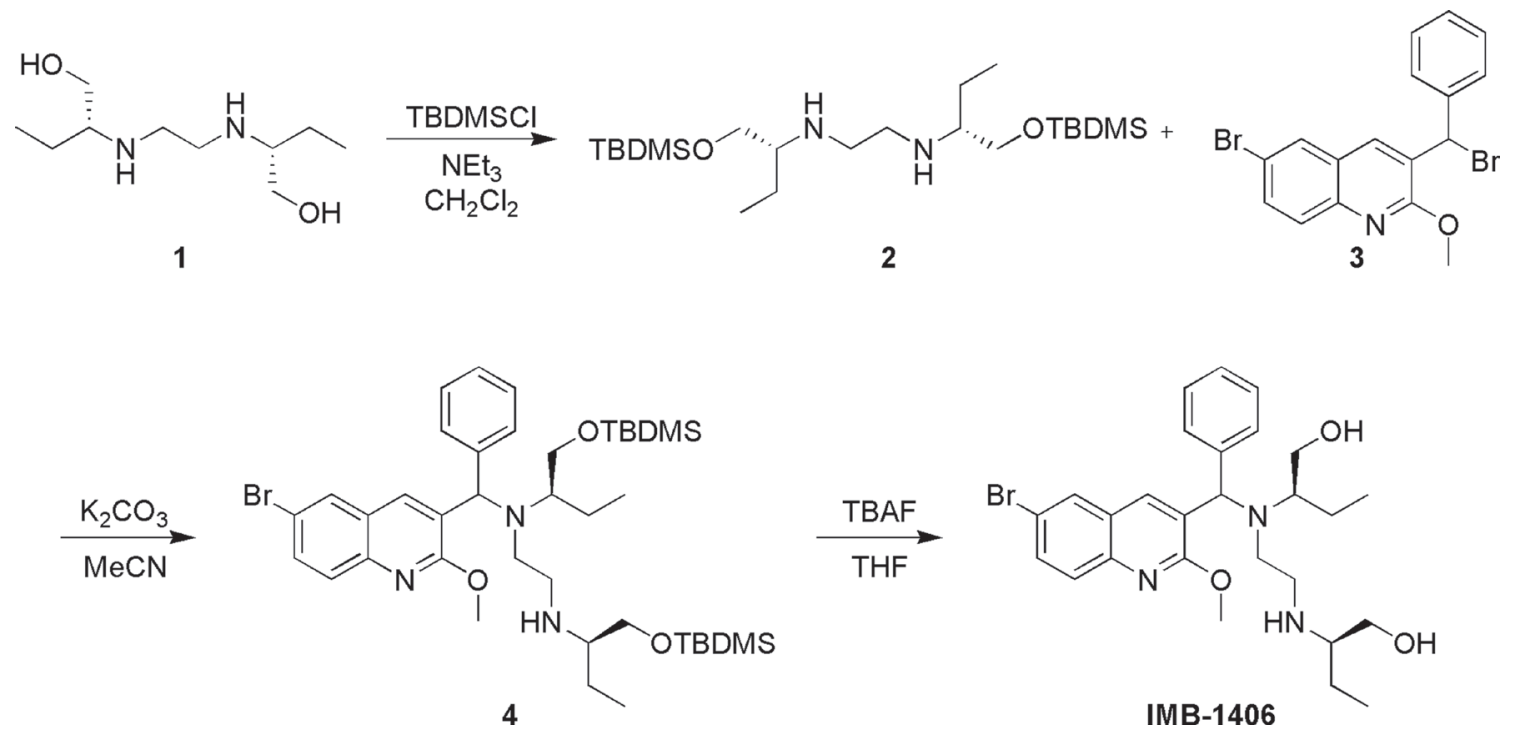

Scheme 1: Synthesis of target compound IMB-1406. (2R)-2-(2-(((6-bromo-2-methoxyquinolin-3-yl)(phenyl)methyl)((R)-1hydroxybutan-2-yl)amino)ethylamino)butan-1-ol (IMB-1406); ${ }^{1} \mathrm{H}$ NMR (400 MHz, DMSO-d6) $\delta 8.70(\mathrm{~s}, 1 \mathrm{H}), 8.12(\mathrm{~d}, J=2.0 \mathrm{~Hz}, 1 \mathrm{H})$, 7.73-7.66 (m, 2H), $7.34(\mathrm{~d}, J=7.2 \mathrm{~Hz}, 2 \mathrm{H}), 5.49(\mathrm{~s}, 1 \mathrm{H}), 4.37$ (brs, 1H), 3.89 (s, 3H), 3.50-3.09 (m, 5H), 2.75-2.60 (m, 3H), 2.33-2.22 (m, $2 \mathrm{H}), 2.09-2.06(\mathrm{~m}, 1 \mathrm{H}), 1.33-1.09(\mathrm{~m}, 4 \mathrm{H}), 0.74(\mathrm{t}, J=7.2 \mathrm{~Hz}, 3 \mathrm{H}), 0.65(\mathrm{t}, J=7.2 \mathrm{~Hz}, 3 \mathrm{H}) ;{ }^{13} \mathrm{C}$ NMR $(101 \mathrm{MHz}, \mathrm{DMSO}-d 6) \delta 160.13$, $143.42,141.47,136.28,131.91,129.69,129.56,129.05,128.44,128.03,126.95,126.49,116.37,62.41,62.34,60.24,53.59,47.08,23.47$, 21.29, 11.93, 9.82. HRMS (m/z) (ESI): calcd for $\mathrm{C}_{27} \mathrm{H}_{37} \mathrm{BrN}_{3} \mathrm{O}_{3}[\mathrm{M}+\mathrm{H}]^{+}:$530.20183; found: 530.20307. 
Table 1: In vitro anti-tumor activity of IMB-1406 and sunitinib against four cell lines

\begin{tabular}{ccccc}
\hline \multirow{2}{*}{ Cell lines } & \multicolumn{2}{c}{ Inhibition rate $(\mathbf{3 0} \boldsymbol{\mu M})$} & \multicolumn{2}{c}{ IC $_{50}(\boldsymbol{\mu M})$} \\
\cline { 2 - 5 } & IMB-1406 & Sunitinib & IMB-1406 & Sunitinib \\
\hline A549 & $100.07 \%$ & $100.02 \%$ & 8.99 & 10.36 \\
HepG2 & $99.98 \%$ & $98.61 \%$ & 6.92 & 7.60 \\
DU145 & $99.93 \%$ & $86.51 \%$ & 7.89 & 7.99 \\
MCF7 & $100.39 \%$ & $88.89 \%$ & 8.26 & 8.65 \\
\hline
\end{tabular}

by Annexin V/PI staining followed by flow cytometry analysis. As shown in Figure 4, treatment of HepG2 cells with IMB-1406 for $72 \mathrm{~h}$ results in an increase of the apoptosis ratios from $8.9 \%$ (untreated vehicle control) to $17.15 \%(2 \mu \mathrm{M}), 35.40 \%(4 \mu \mathrm{M})$ or $57.51 \%(8 \mu \mathrm{M})$, indicating that IMB-1406 is able to induce apoptotic cell death in HepG2 cells in a concentration-dependent manner.

\section{Effects of IMB-1406 on mitochondrial membrane potential of HepG2 cells}

In order to determine the plausible pathway by which IMB-1406 triggers cell apoptosis, the changes of mitochondrial membrane potential were assessed. The uptake of 5,5',6,6'-tetrachloro -1, $1^{\prime}, 3,3^{\prime}$ tetraethylbenzimidazol-carbocyanine iodide (JC-1), a lipophilic cationic fluorescent dye accumulated in mitochondria, is positively correlated with the mitochondrial membrane potential [27]. HepG2 cells were treated with different concentrations $(0,2,4,8 \mu \mathrm{M})$ of IMB-1406 for $72 \mathrm{~h}$ prior to staining with $\mathrm{JC}-1$. Then the numbers of cells with collapsed mitochondrial membrane potential in different cell groups were determined by flow cytometric analysis. As shown in Figure 5, the percentage of cells with typical apoptotic morphology increases in a dose-dependent fashion $(0.53 \%, 6.14 \%, 13.8 \%$ and $34.92 \%$, respectively). Our results reveal that incubation with IMB-1406 increases the number of cells with collapsed mitochondrial membrane potentials and induces apoptosis.
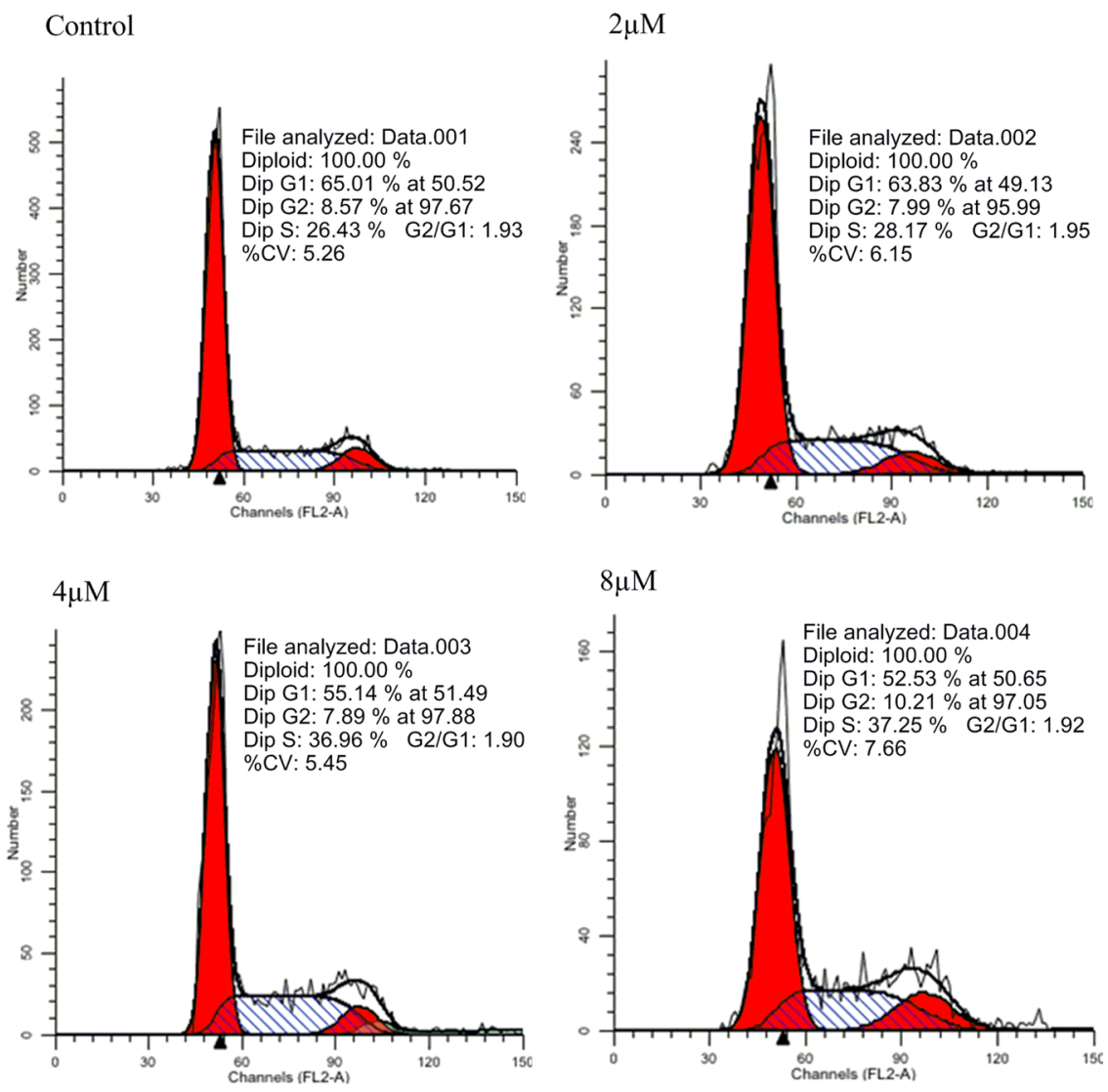

Figure 3: Effects of IMB-1406 on cell cycle of HepG2 cells. HepG2 cells were treated with the indicated concentrations of IMB-1406 for $72 \mathrm{~h}$ and stained with PI, followed by flow cytometry analysis. 


\section{Effects of IMB-1406 on the levels of Bax, Bcl-2 and caspase-3}

Mitochondria play an essential role in cell death signal transduction. The mitochondria-dependent apoptotic apoptotic proteins, which induce the permeabilization of the mitochondrial outer membrane, resulting in the activation of the caspase cascade and the induction of apoptotic cell death [28, 29]. To explore the possible role of a mitochondrial-related pathway in IMB-1406induced apoptosis, the effects of IMB-1406 on the levels of Bax, Bcl-2 and caspase-3 were examined by Western blot analysis. As shown in Figure 6, IMB-1406 treatment shows concentration-dependent effects in upregulating the expressions of Bax and downregulating Bcl-2. In addition, caspase- 3 is activated in a concentration-dependent manner after treatment with IMB-1406 at $2 \mu \mathrm{M}, 4 \mu \mathrm{M}$ and $8 \mu \mathrm{M}$ for $72 \mathrm{~h}$. These results reveal that IMB-1406 induces apoptosis in HepG2 cancer cells via a mitochondriadependent pathway. pathway is regulated by the Bcl-2 family of pro- and anti-

\section{MATERIALS AND METHODS}

\section{Virtual screening}

The representative crystal structure of farnesyltransferase (PDB ID 3E30) was obtained from the Protein DataBank. Initially there was a pretreatment process for both the ligands and the enzymes. For ligand preparation, all the duplicate structures were removed and options for ionization change, tautomer generation, isomer generation, Lipinski filter and 3D generator were set true. For enzyme preparation, the whole enzyme was selected, waters were removed and hydrogen atoms were added to it. The $\mathrm{pH}$ of theprotein was set in the range of 6.5 to 8.5. Then we defined the enzyme as a total receptor and the binding site was defined by selecting the important amino acids for catalysis to generate a $10 \AA$ radius sphere by the operation of Define and Edit Binding Site. Docking of compounds into enzymes with CDOCKER was done using the default parameters. The pose with the top -CDOCKER_INTERACTION_ENERGY was chosen for analyzing the binding features.

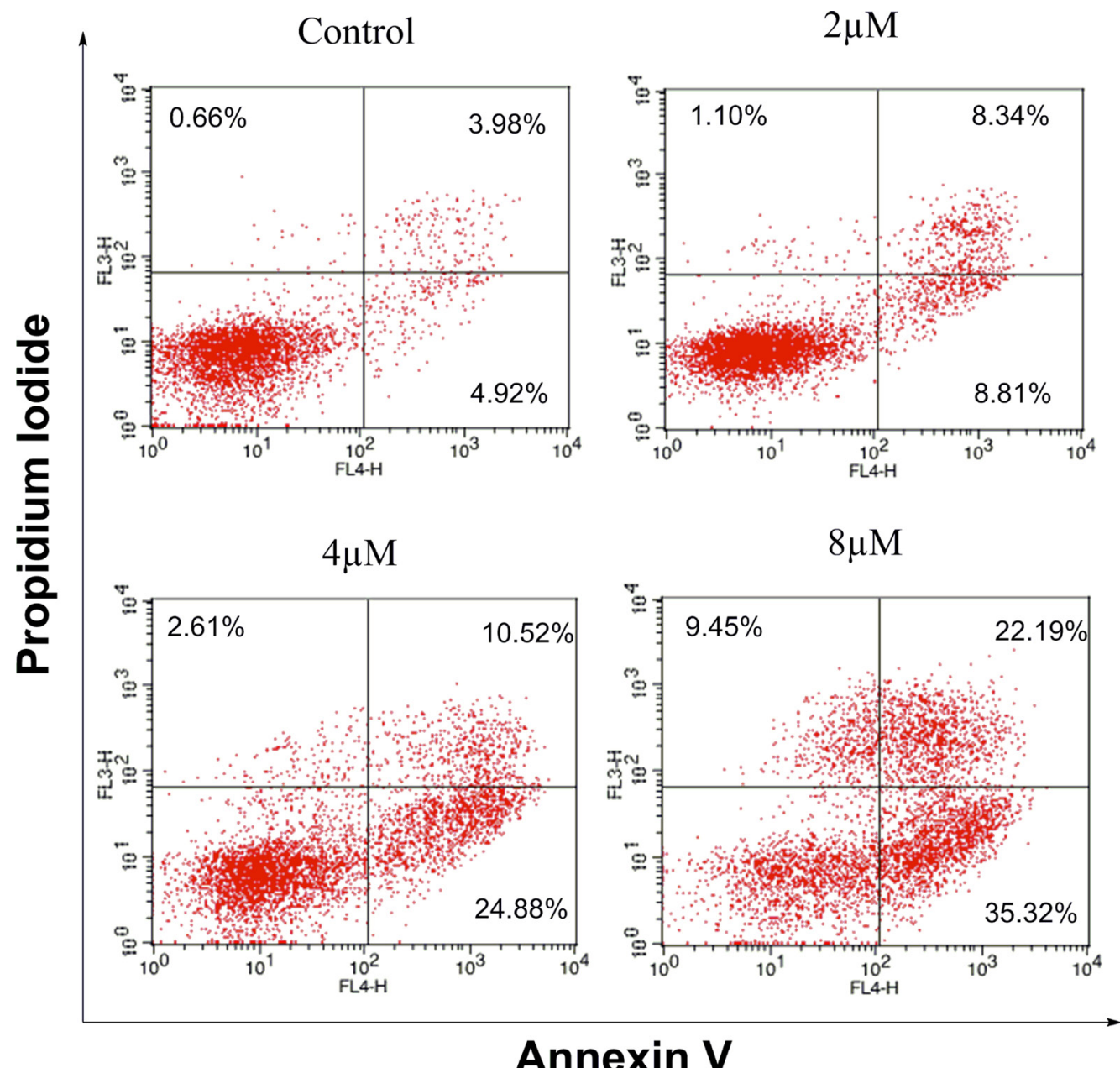

Figure 4: Effects of IMB-1406 on induction of HepG2 cell apoptosis. HepG2 cells were treated with the indicated concentrations of IMB-1406 for $72 \mathrm{~h}$ and stained with Annexin V/PI, followed by flow cytometry analysis. The percentage of cell positive for PI and/or Annexin V-FITC are reported inside the quadrants. 
Control

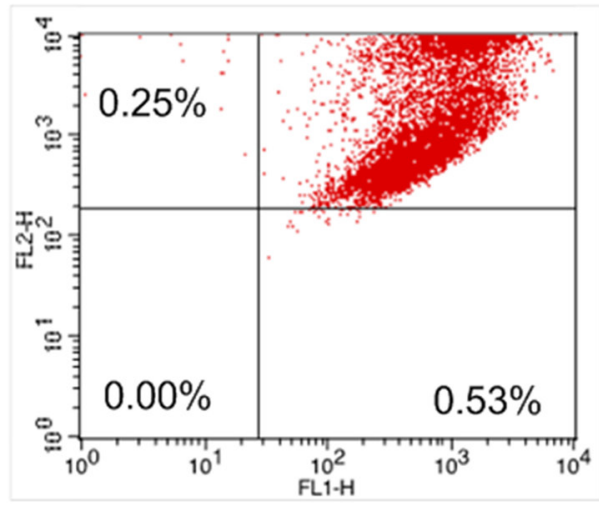

$4 \mu \mathrm{M}$

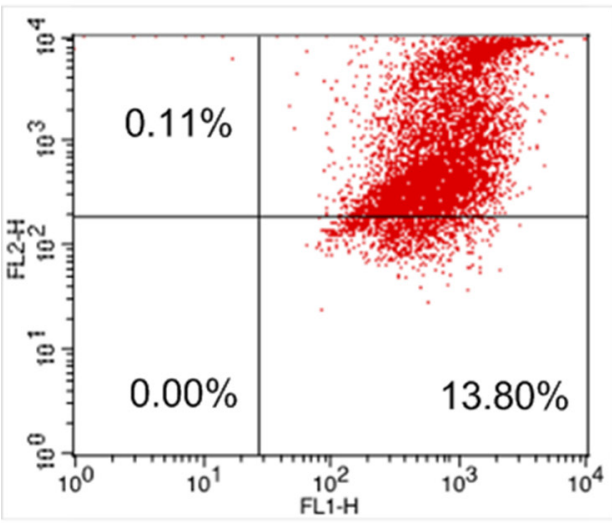

$2 \mu \mathrm{M}$

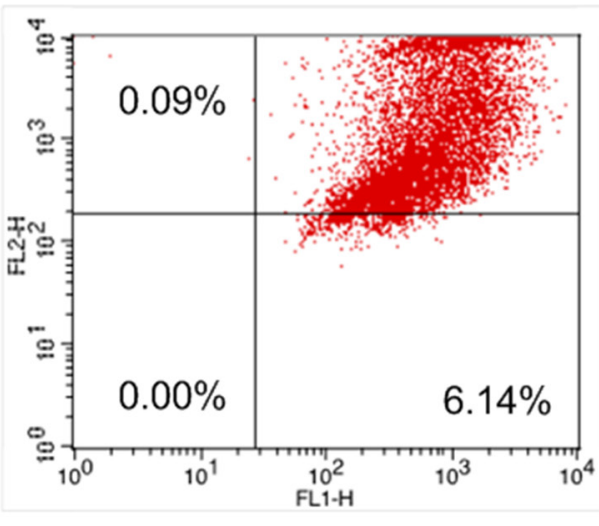

$8 \mu \mathrm{M}$

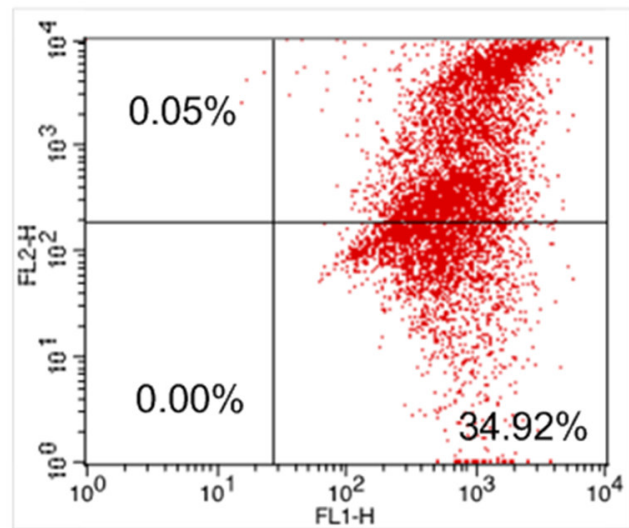

Figure 5: JC-1 mitochondrial membrane potential staining of IMB-1406 in of HepG2 cells. HepG2 cells were treated with the indicated concentrations of IMB-1406 for $72 \mathrm{~h}$ and stained with JC-1, followed by flow cytometry analysis.

IMB-1406

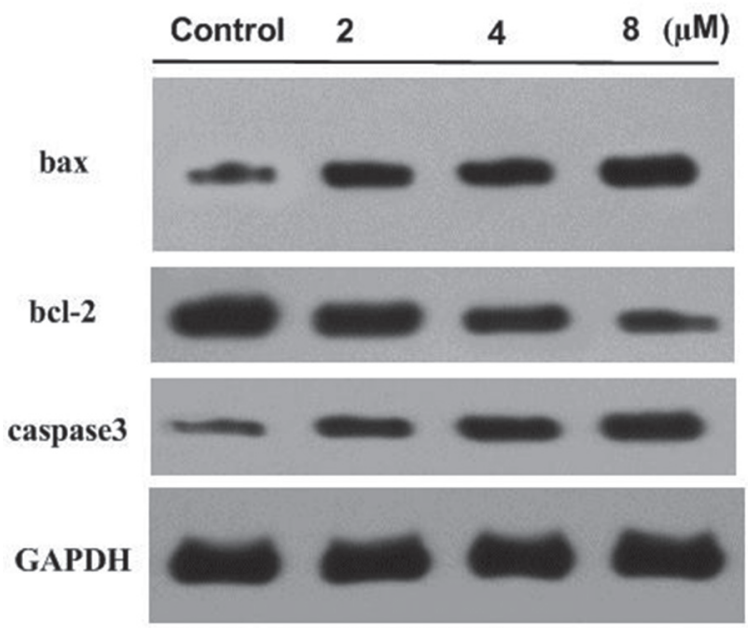

Figure 6: Effects of IMB-1406 on the levels of Bax, Bcl-2 and caspase-3. HepG2 cells were treated with IMB-1406 at $2 \mu \mathrm{M}$, $4 \mu \mathrm{M}$ and $8 \mu \mathrm{M}$ for $72 \mathrm{~h}$. The cell lysates were collected and expression levels of Bax, Bcl-2 and caspase- 3 were determined by western blot analysis. GADPH was used as internal control. 


\section{Chemistry}

All the reagents were purchased from commercial suppliers and were used without further purification unless otherwise indicated. Reaction courses were monitored by TLC on silica gel precoated F254 Merck plates. Developed plates were examined with UV lamps (254 nm). ${ }^{1} \mathrm{H}-\mathrm{NMR}$ and ${ }^{13} \mathrm{C}$-NMR spectra were taken on a Bruker spectrometer using TMS as the internal standard. DMSO- $\mathrm{d}_{6}$ and $\mathrm{CDCl}_{3}$ were used as the solvent. Mass spectra were measured on an Agilent 1100 series.

\section{General procedure for the synthesis of intermediate 2}

To a solution of ethambutol dihydrochloride $(1,2.77 \mathrm{~g}, 10 \mathrm{mmol})$ and $\mathrm{Et}_{3} \mathrm{~N}(5.70 \mathrm{ml}, 44 \mathrm{mmol})$ in anhydrous DCM (100ml) was added dropwise a solution of tert-butyldimthylsilyl chloride $(3.30 \mathrm{~g}, 22 \mathrm{mmol})$ in anhydrous DCM $(20 \mathrm{ml})$ at $0^{\circ} \mathrm{C}$. After the addition, the mixture was stirred at room temperature for $2 \mathrm{~h}$ and then washed with water $(150 \mathrm{ml})$, satd. $\mathrm{NaHCO}_{3}(100 \mathrm{ml})$ and brine $(100 \mathrm{ml})$. The organic fractions were dried over anhydrous magnesium sulfate. The solvent was removed in vacuo to yield $2(4.72 \mathrm{~g}, 80.5 \%)$ as a colourless oil.

\section{General procedure for the synthesis of intermediate 4}

Anhydrous potassium carbonate $(0.83 \mathrm{~g}, 3 \mathrm{mmol})$ was added to a solution of $2(1.30 \mathrm{~g}, 3 \mathrm{mmol})$ and 3 (200 $\mathrm{mg}, 0.5 \mathrm{mmol})$ in acetonitrile $(10 \mathrm{ml})$. The resulting mixture was reflux for overnight, after which the reaction mixture was poured into water $(20 \mathrm{ml})$, and extracted with DCM $(3 \times 20 \mathrm{ml})$. The combined organic extracts were washed with satd. $\mathrm{NaHCO}_{3}(2 \times 30 \mathrm{ml})$ and brine $(30 \mathrm{ml})$, dried over anhydrous magnesium sulfate and solvents removed in vacuo to obtain the crude reaction mixture. Further purification was performed by silica flash column chromatography eluting with DCM/MeOH (95:5), affording 4 as a light yellow oil $(0.26 \mathrm{~g}, 69.5 \%)$.

\section{General procedure for the synthesis of IMB-1406}

The solution of compound $4(0.28 \mathrm{~g}, 0.37 \mathrm{mmol})$ in THF ( $5 \mathrm{ml}$ ) and $1 \mathrm{M}$ TBAF (in THF, $1.37 \mathrm{ml}, 1.48 \mathrm{mmol}$ ) were allowed to react at room temperature for $10 \mathrm{~h}$, then the reaction mixture was concentrated and purified silica flash column chromatography $(0-10 \%(\mathrm{v} / \mathrm{v}) \mathrm{MeOH}$ in DCM). The collected fraction were evaporated to afford the alcohol IMB-1406 as a white solid (90.2 mg, 45.9\%).

\section{Biological assay}

\section{Cell lines and culture}

Cell lines of A549, MCF-7, DU145 and HepG2 were provided by Nanjing KeyGen Biotech. Inc. All of these cells were cultured in Dulbecco's modified Eagle's medium (DMEM, Invitrogen) containing 10\% calf serum (CS) and grown in a humidified atmosphere of $5 \% \mathrm{CO}_{2}$ at $37^{\circ} \mathrm{C}$.

\section{Reagents}

The Annexin V- APC/7-AAD Apoptosis Detection kit, Cell cycle detection kit, Mitochondrial membrane potential detection kit, SDS-PAGE gel preparation kit and the enhanced chemiluminescence (ECL) kit were purchased from Nanjing KeyGen Biotech Co., Ltd. (Nanjing, China). DMSO and MTT were purchased from Sigma-Aldrich (Merck Millipore, Darmstadt, Germany). Other reagents were purchased from Beyotime Institute of Biotechnology (Jiangsu, China).

\section{MTT assay}

Cell growth inhibition was determined using a colorimetric MTT assay. The assay was conducted in a 96-well plate with a cell density of $8 \times 10^{3}$ cells per well with an incubation period of $24 \mathrm{~h}$. The cells were then incubated with different concentrations of IMB-1406 ( 0 , $20,40,80,160$ and $320 \mathrm{mg} / \mathrm{l}$ ) in triplicate. After 24, 48 and $72 \mathrm{~h}$ of incubation, the cells were incubated with medium containing MTT for $4 \mathrm{~h}$, and the formazan crystals were dissolved with $150 \mu 1$ DMSO. The dark blue MTT crystals were dissolved by agitating the plates at room temperature for $10 \mathrm{~min}$, and the absorbance was then measured at $490 \mathrm{~nm}$ with a microplate reader (OLYMPUS IX51, Japan).

\section{Apoptosis detection assay}

HepG2 cells were seeded into 6-well plates and treated with IMB-1406 at different concentrations for $72 \mathrm{~h}$. Apoptosis was then detected by the following procedures.

\section{Flow cytometry analysis of Annexin V-APC/7- AAD staining}

HepG2 cells were inoculated in 6-well plates and then processed accordingly after they adhered. Cells were treated with IMB-1406, after $72 \mathrm{~h}$ the cells were collected by trypsin without EDTA, washed twice with PBS. The Annexin V-APC/7-AAD Apoptosis Detection kit (KGA1024, KeyGEN, Nanjing, China) was used for cell staining and flow cytometry (Becton-Dickinson FACS Calibur) following the manufacturer's instructions. The percentage of apoptotic cells was determined using FACS flow cytometry and associated software (BECKMAN). Experiments were repeated three times, and the results are displayed as histograms.

\section{Cell cycle detection}

Cells in the logarithmic phase of growth were digested by trypsin and centrifuged. After counting, 
the cells were inoculated in 6-well plates. Cells were processed accordingly after they adhered. Whereafter, the cells were collected and washed with $1 \times$ PBS, and then $70 \%$ ethyl alcohol was added for fixation overnight. After the supernatant was removed, the cells were washed with $1 \times$ PBS. Once the RNA enzyme was added, the cells were placed at $37^{\circ} \mathrm{C}$ for 30 minutes. After digestion, PI was added for staining. Then, the cells were placed in the dark at $4^{\circ} \mathrm{C}$ for 30 minutes. The PI-stained protoplasts were measured by flow cytometry with an excitation wavelength of $488 \mathrm{~nm}$.

\section{Measurement of mitochondrial membrane potential}

HepG2 cells were inoculated in 6-well plates and then processed accordingly after they adhered. Cells were treated with IMB-1406, after $72 \mathrm{~h}$ the cells were collected, washed once with PBS and resuspended in fresh medium containing 5, 5',6 , 6'tetrachloro-1, 1', 3, 3'-tetraethylbenzimidazolcarbocyanine iodide (JC-1). After incubation at $37^{\circ} \mathrm{C}$ for 15 20 minutes under a humidified atmosphere containing $5 \% \mathrm{CO}_{2}$, cells were analyzed by flow cytometry with an excitation wavelength of $488 \mathrm{~nm}$.

\section{Detecting protein by western blot}

Cell total protein extraction was performed, followed by sodium dodecyl sulfate-polyacrylamide gel electrophoresis, transmembrane antibody incubation, and color development.

\section{CONCLUSIONS}

In summary, a new compound (IMB-1406) was identified, synthesized and characterized by ${ }^{1} \mathrm{HNMR}$, ${ }^{13} \mathrm{CNMR}$ and MS. IMB-1406 was found to have considerable potency $\left(\mathrm{IC}_{50} \mathrm{~s}: 6.92-8.99 \mu \mathrm{M}\right)$ which is better than Sunitinib against all four cancer cell lines tested. Moreover, preliminary study on mechanism revealed that IMB-1406 induces apoptosis in HepG2 cells by arresting the cell cycle at the $\mathrm{S}$ phase, altering anti- and proapoptotic proteins leading to mitochondrial dysfunction and activation of caspase-3. Meanwhile, molecular docking study suggested one of the possible targets for IMB-1406 was protein farnesyltransferase. Together, IMB-1406 is a novel conjugate with potent antitumor activity, and it could contribute to a better understanding of structure-based drug design to facilitate drug discovery. Based on this, further structural modifications, SAR studies and enzyme inhibitory activity of IMB-1406 are currently in progress.

\section{ACKNOWLEDGMENTS AND FUNDING}

This work was supported by National Key Research and Development Program (2016YFA0201500), the
National S\&T Major Special Project on Major New Drug Innovations (Nos.162 2014ZX09507009-003, 2015ZX09102007-008), NSFC (Nos.163 81373267, 21502237) and CAMS Innovation Fund for Medical Sciences (2016-I2M-3-012, 2016-I2M-3-022).

\section{CONFLICTS OF INTEREST}

None.

\section{REFERENCES}

1. Torre LA, Bray F, Siegel RL, Ferlay J, Lortet-Tieulent J, Jemal A. Global cancer statistics, 2012. CA Cancer J Clin. 2015; 65:87-108. doi: 10.3322/caac.21262.

2. Levitzki A. Tyrosine kinase inhibitors: views of selectivity, sensitivity, and clinical performance. Annu Rev Pharmacol Toxicol. 2013; 53:161-85. doi: 10.1146/annurevpharmtox-011112-140341.

3. Paquette RL, Landaw EM, Pierre RV, Kahan J, Lubbert M, Lazcano O, Isaac G, McCormick F, Koeffler HP. N-ras mutations are associated with poor prognosis and increased risk of leukemia in myelodysplastic syndrome. Blood. 1993; 82:590-9.

4. Appels NM, Beijnen JH, Schellens JH. Development of farnesyl transferase inhibitors: a review. Oncologist. 2005; 10:565-78. doi: 10.1634/theoncologist.10-8-565.

5. Konstantinopoulos PA, Karamouzis MV, Papavassiliou AG. Post-translational modifications and regulation of the RAS superfamily of GTPases as anticancer targets. Nat Rev Drug Discov. 2007; 6:541-55. doi: 10.1038/nrd2221.

6. Adjei AA. Blocking oncogenic Ras signaling for cancer therapy. J Natl Cancer Inst. 2001; 93:1062-74.

7. Johnston SR. Farnesyl transferase inhibitors: a novel targeted tnerapy for cancer. Lancet Oncol. 2001; 2:18-26.

8. Karp JE, Kaufmann SH, Adjei AA, Lancet JE, Wright JJ, End DW. Current status of clinical trials of farnesyltransferase inhibitors. Curr Opin Oncol. 2001; 13: 470-6.

9. Tsimberidou AM, Chandhasin C, Kurzrock R. Farnesyltransferase inhibitors: where are we now? Expert Opin Investig Drugs. 2010; 19:1569-80. doi: 10.1517/13543784.2010.535516.

10. Ma Y, Wang SQ, Xu WR, Wang RL, Chou KC. Design novel dual agonists for treating type-2 diabetes by targeting peroxisome proliferator-activated receptors with core hopping approach. PLoS One. 2012; 7:e38546. doi: 10.1371/journal.pone.0038546.

11. Liu L, Ma Y, Wang RL, Xu WR, Wang SQ, Chou KC. Find novel dual-agonist drugs for treating type 2 diabetes by means of cheminformatics. Drug Des Devel Ther. 2013; 7: 279-88. doi: 10.2147/DDDT.S42113.

12. Sirois S, Wei DQ, Du Q, Chou KC. Virtual screening for SARS-CoV protease based on KZ7088 pharmacophore 
points. J Chem Inf Comput Sci. 2004; 44:111-22. doi: 10.1021/ci034270n.

13. Wang MY, Jin YY, Wei HY, Zhang LS, Sun SX, Chen XB, Dong WL, Xu WR, Cheng XC, Wang RL. Synthesis, biological evaluation and 3D-QSAR studies of imidazolidine-2,4-dione derivatives as novel protein tyrosine phosphatase 1B inhibitors. Eur J Med Chem. 2015; 103:91-104. doi: 10.1016/j.ejmech.2015.08.037.

14. Langer T, Wolber G. Pharmacophore definition and 3D searches. Drug Discov Today Technol. 2004; 1:203-7. doi: 10.1016/j.ddtec.2004.11.015.

15. Mehra R, Rani C, Mahajan P, Vishwakarma RA, Khan IA, Nargotra A. Computationally Guided Identification of Novel Mycobacterium tuberculosis GlmU Inhibitory Leads, Their Optimization, and in Vitro Validation. ACS Comb Sci. 2016; 18:100-16. doi: 10.1021/acscombsci.5b00019.

16. Cai L, Wang Y, Wang JF, Chou KC. Identification of proteins interacting with human SP110 during the process of viral infections. Med Chem. 2011; 7:121-6.

17. Liao QH, Gao QZ, Wei J, Chou KC. Docking and molecular dynamics study on the inhibitory activity of novel inhibitors on epidermal growth factor receptor (EGFR). Med Chem. 2011; 7:24-31.

18. Wu G, Robertson DH, Brooks CL 3rd, Vieth M. Detailed analysis of grid-based molecular docking: A case study of CDOCKER-A CHARMm-based MD docking algorithm. J Comput Chem. 2003; 24:1549-62. doi: 10.1002/jcc.10306.

19. McEneny-King A, Edginton AN, Rao PP. Investigating the binding interactions of the anti-Alzheimer's drug donepezil with CYP3A4 and P-glycoprotein. Bioorg Med Chem Lett. 2015; 25:297-301. doi: 10.1016/j.bmcl.2014.11.046.

20. Abuo-Rahma Gel D, Abdel-Aziz M, Farag NA, Kaoud TS. Novel 1-[4-(Aminosulfonyl)phenyl]-1H-1,2,4-triazole derivatives with remarkable selective COX-2 inhibition: design, synthesis, molecular docking, anti-inflammatory and ulcerogenicity studies. Eur J Med Chem. 2014; 83: 398-408. doi: 10.1016/j.ejmech.2014.06.049.

21. Jug G, Anderluh M, Tomasic T. Comparative evaluation of several docking tools for docking small molecule ligands to DC-SIGN. J Mol Model. 2015; 21:164. doi: 10.1007/ s00894-015-2713-2.

22. Xiao J, Zhang S, Luo M, Zou Y, Zhang Y, Lai Y. Effective virtual screening strategy focusing on the identification of novel Bruton's tyrosine kinase inhibitors. J Mol Graph Model. 2015; 60:142-54. doi: 10.1016/j.jmgm.2015.05.005.

23. Hast MA, Fletcher S, Cummings CG, Pusateri EE, Blaskovich MA, Rivas K, Gelb MH, Van Voorhis WC, Sebti SM, Hamilton AD, Beese LS. Structural basis for binding and selectivity of antimalarial and anticancer ethylenediamine inhibitors to protein farnesyltransferase. Chem Biol. 2009; 16:181-92. doi: 10.1016/j. chembiol.2009.01.014.

24. Wang M, Ye C, Liu M, Wu Z, Li L, Wang C, Liu X, Guo H. Synthesis and antitumor activity of 5-(5-halogenated-2oxo-1H-pyrrolo[2,3-b]pyridin-(3Z)-ylidenemethyl)-2,4dimethyl- 1H-pyrrole-3-carboxamides. Bioorg Med Chem Lett. 2015; 25:2782-7. doi: 10.1016/j.bmcl.2015.05.017.

25. Bunz F. Cell death and cancer therapy. Curr Opin Pharmacol. 2001; 1:337-41.

26. Reed JC. Apoptosis-regulating proteins as targets for drug discovery. Trends Mol Med. 2001; 7:314-9.

27. He XL, Zhang P, Dong XZ, Yang MH, Chen SL, Bi MG. JR6, a new compound isolated from Justicia procumbens, induces apoptosis in human bladder cancer EJ cells through caspase-dependent pathway. J Ethnopharmacol. 2012; 144: 284-92. doi: 10.1016/j.jep.2012.09.010.

28. Pandey P, Saleh A, Nakazawa A, Kumar S, Srinivasula SM, Kumar V, Weichselbaum R, Nalin C, Alnemri ES, Kufe D, Kharbanda S. Negative regulation of cytochrome c-mediated oligomerization of Apaf-1 and activation of procaspase-9 by heat shock protein 90 . EMBO J. 2000; 19 : 4310-22. doi: 10.1093/emboj/19.16.4310.

29. Brentnall M, Rodriguez-Menocal L, De Guevara RL, Cepero E, Boise LH. Caspase-9, caspase-3 and caspase-7 have distinct roles during intrinsic apoptosis. BMC Cell Biol. 2013; 14:32. doi: 10.1186/1471-2121-14-32. 